\title{
Papers
}

Explorations into Children's Literature

\section{Inertia to Action: From Narrative Empathy to Political Agency in Young Adult Fiction}

\author{
Lindsay Morton and Lynnette Lounsbury
}

\begin{abstract}
'Now tell me...' Tobias says through a bursting breath, 'what do you think learning strategy has to do with...bravery?' The question reminds me that he is my instructor, and I am supposed to learn something from this. A cloud passes over the moon, and the light shifts across my hands.

'It...it prepares you to act,' I say finally. 'You learn strategy so you can use it.' (Roth 2011, pp. 143-4)
\end{abstract}

In this passage from Veronica Roth's young adult (YA) novel Divergent (2011), protagonist Tris Prior is encouraged to make a connection between knowledge and action. More specifically, her instructor Tobias prompts Tris to articulate that strategy is necessary preparation for action. Implicit in this meta-teaching moment is an invitation for readers to embark with Tris on a journey that is exhilarating, but also instructive. Here Roth cues a generic feature of YA dystopian fiction: its function as a roadmap to agency. YA series such as Divergent (Roth 2011; 2012; 2013), The Hunger Games (Collins 2010a; 2010b; 2013), and The Maze Runner (Dashner 2010; 2011; 2013) all feature protagonists who move from inertia to action to engage with powerful enemies in a struggle for freedom and liberty. Given the genre's overtly political concerns, this paper aims to consider what, if any, real-world empowerment might occur for readers who respond empathically to YA dystopian fiction. It explores how these texts might act as roadmaps to political agency and social activism, and asks whether-by mobilising readers' affective responses-YA fiction might in fact immobilise young adults. In short, this paper examines whether there is there any evidence to 
suggest YA dystopian texts have the potential to empower a new generation of young adults to move from political inertia to action.

Drawing on research in the field of narrative empathy, this paper argues that although there is no clear evidence to suggest YA dystopian fiction acts as a trigger for political action, it can inspire and energise those who are already politically active. Research further suggests that strong experiences of narrative empathy can predispose individuals to respond to future calls for activism, indicating that dystopian YA fiction is a space where young adults can learn patterns of thinking and action to help them actively negotiate the political world. To put it in Tris’ terms, reading YA dystopian fiction: 'prepares you to act' (2011, p. 144).

YA fiction has been both criticised and praised for its potential to trigger political engagement in a group often described as an 'inert', 'passive', and 'disengaged' generation. Of course, this type of labeling is both reductive and pessimistic; it is also a relatively recent phenomenon. 'Teens' were first identified as a distinct social and consumer group in the 1940s and 1950s. Typical group traits and social dynamics were described and, as social perceptions developed about what a teenager should be like, the 'teenager' became a labeled individual. Skelton and Valentine (1998) highlight the threatening nature of what they call the 'quarantine period' of the teenage years: tension arises when teens transgress the fuzzy boundaries of youth and adulthood, causing reflexive and often arbitrary power plays by adults (pp. 4-5). While more recent imaginings of youth see this period as a free-range time of adventurous travel and over-consumption (1998, p. 5), psychologist Robert Epstein (2007) argues that Western culture has arbitrarily limited the power of a group of citizens within society and kept them inert, restricted, and powerless (p. 59). He further posits that teens are as mature as adults in many regards and find a lack of responsibility debilitating (2007, p. 58). Social geographer David Sibley (1995) believes that restricting adolescents reflects an adult desire to place boundaries where none naturally exist - a desire to turn the process of growth into discrete and arbitrarily numeric categories (p. 35). This allows for control over a group whose energy and physical capacity for action make them simultaneously adult and child, thus threatening to adults ( p. 35). YA fiction highlights the effects of repression by adults, ostensibly aiming to counteract the real-world flow of power through its portrayal of active adolescents. 
Roberta Seelinger Trites (1998) proposes that the exploration of power is integral to any real growth in a young adult reader. She argues that while reading about power may not change anything materially for the young adult, it facilitates an understanding of the gradations between powerlessness and power that will be translated into real world understanding and action (1998, p. x). Trites builds on Michel Foucault's (1980) suggestion that power is a 'perpetual relationship of force', a form of movement in which one never possesses power and, instead, only engages with it when applying it (p. 89). It is only when one goes against the flow of power that one is repressed, and only when one applies force that one is powerful: critically, without action, the idea of power is moot (1980, pp. 89-98). Judith Butler (1990) extends this notion of a 'force', suggesting that there is more to the relationship between power and oppression - that power does not merely act 'upon' individuals, it 'enacts' them. She agrees with Foucault's analysis of power as a process of reaction, but allows that it may also be one of internal proactivity (p. 13). Power can be understood, then, as 'a force that operates within the subject and upon the subject in adolescent literature' (Trites 1998, p. 7); it is also inherent in the process of becoming knowledgeable. Reading texts about power is a power relationship in and of itself, and the growing field of research into narrative empathy and the novel can begin to illuminate how this process works.

Research conducted on the affective experience of reading narrative fiction indicates that there are close links between emotion, cognition, sympathy, empathy, and identification. For example, Mar et al. (2011) argue that after a powerful emotional experience, 'effects on cognition, perception, and action would be expected, in agreement with the wide range of influences demonstrated by emotion researchers' (p. 829, emphasis added). They describe a 'cognitive mechanism' by which people select goals and accomplish actions in the real world , and assert that such a 'planning processor' can be mobilised when readers suspend their own goals, plans and actions to 'empathise and identify with fictional characters' in a diegetic world (p. 824). Empathy here is distinguished from identification, as empathy does not require that readers see themselves as the character, whereas in identification 'we take on [a character's] goals and plans as our own, and see ourselves as the character feeling what he or she feels' (p. 824, emphasis added). For Mar et al., then, a powerful affective reading experience may trigger an appropriation of goals, plans and actions to align with those of the characters that elicit empathy. Miall and Kuiken (2002) propose that 'aesthetic and narrative feelings [such as empathy] interact to produce metaphors of personal identification that modify self-understanding' (p. 229). The term 'self-modifying feelings' refers to 'a 
distinctive process within which... an existing feeling is decisively recontextualised' (p. 223). In the process of reading narrative fiction, for example, a reader's affective experience may 'simulate' that of the protagonist, as feeling functions mimetically when the reader is empathetically engaged (Oatley 2009, p. 221). Miall and Kuiken (2002) stress that 'selfmodifying feelings are evident only among certain readers - and among them only some of the time' (p. 229), but the key point is that reader identification can recontextualise the thoughts, feelings, and critically, the real-world goals of a reader.

While theorists such as Oatley (2009) treat identification as 'a literary term for empathy', others are careful to separate the terms (p. 210). Keen (2007), for example, describes empathy as a potential product of identification. It is 'a vicarious, spontaneous sharing of affect' that 'can be provoked by witnessing another's emotional state, by hearing about another's condition, or even by reading [a novel]' ( p. 4). She argues elsewhere that while no research has verified that novel reading encourages pro-social action and good world citizenship, readers may 'still internalize the experience of empathy with possible later real-world responsiveness to others' needs' (2006, p. 224). Keen continues:

While a full-fledged political movement, an appropriately inspiring social context, or an emergent structure of feeling promoting change may be necessary for efficacious action to arise out of internalized experience of narrative empathy, readers may respond in those circumstances as a result of earlier reading. (p. 220)

Keen's phrase 'internalized experience of narrative empathy' corresponds with the concept of a ‘cognitive mechanism' (Mar et al. 2011) appropriated to a fictional world, as well as ‘selfmodifying feelings' (Miall and Kuiken 2002), which recontextualise existing feelings to simulate the experience of a character in a book.

Each of these positions indicate that readers can be (re)oriented to a new set of plans, goals, or actions through identification with—or empathy for-a fictional character. In this way, the metaphor of a 'road-map' is an apt description of a reader aligning with narrative intent. Significantly, however, Keen's research indicates there is still a gap between intention and action after an intense, internalised reading experience. These points lead towards the conclusion that while YA dystopian fiction may not act as a trigger for political action, it can inspire and energise individuals and groups who are already politically active. Alternatively, individuals who move from political inertia to action at a future date may recontextualise their textual empathic response, using it to guide their newfound political aims. 
As with cognitive theorists, YA literary critics are divided on the genre's potential to trigger political action. Arguments in favour suggest that YA texts function as triggers for political action by compelling readers' attention through a 'scared straight' approach. They encourage readers to face inconvenient truths (Ostry 2013, pp. 110-11), sensitise or predispose young adults to political action (Hintz and Ostry 2003, p. 7), and they call readers to action through paratextual spaces that bridge the gap between real and diegetic worlds (Morrissey 2013, p. 199). Others are less optimistic, noting that the pervasive hopelessness in the dystopian genre (Broad 2013, p. 80) and excessively bleak portrayals of futuristic societies may mean readers cannot recognise their own contemporary society in fictional worlds (Couzelis 2013, p. 113). It has also been noted that readers might react against YA fiction's implicit criticism of contemporary adolescent culture, thus inhibiting their desire to become politically motivated (Ostry 2013 p. 110). However, there is significant agreement between these schools of thought in their acknowledgement of empathy as a key factor in predisposing readers for action. If readers are able to recognise themselves and their society in the diegetic worlds, and crucially, if there is some hope for redemption or reformation, readers may indeed be able to appropriate affective reading experiences in preparation for political action. Learning how to be strategic prepares Tris Prior to act, but the question to be explored in the following section is whether The Hunger Games, Divergent, and The Maze Runner trilogies are effective calls to action.

The trope of early adolescence as a waiting space is a common feature of YA fiction. The protagonists of the texts under consideration here, Tris, Tobias, Thomas, and Katniss are initially presented as largely powerless, with access to little or no information, or misinformation about how their world works. Yet, despite being oppressive, heavilyregulated places, the waiting spaces they occupy-District 12, the Abnegation sector, and the Maze-are where the protagonists learn the core skills and attributes they will need in order to act. When readers first meet Katniss Everdeen in The Hunger Games, it is the morning of the reaping. She is waiting for 2:00 pm, when the district will gather to find out who the next tributes will be. However, Katniss has not been wasting her preparation time: she is a skilled hunter and provider, has parenting instincts, and is a fierce negotiator. Katniss' failed attempts to drown her sister Prim’s cat also signal her potential for ruthless pragmatism. For Simmons (2012), Katniss' 'uncertain impulsivity’ and her complex mix of strength, bravery and fragility are entry points for reader empathy and, potentially, identification ( pp. 22-23). 
The empathic narrative strategies that invite identification in The Hunger Games trilogy can be characterised as 'bounded strategic empathy'. Keen (2008) describes 'bounded strategic empathy' as an author directing:

an emotional transaction through a fictional work aimed at a particular audience, not necessarily including every reader who happens upon the text. ...[It] addresses chosen others with the aim of cultivating their empathy for the in-group, often to a specific end. (p. 483)

The choice of Katniss as the focalising character may indicate that Suzanne Collins' 'particular audience' chosen for a 'specific end' is politically disengaged adolescents (Keen 2008, p. 483). Although Katniss is physically active, her initial attitude towards the Capitol is passive. Access to historical information untainted by the Capitol's propaganda is, of course, unlikely in District 12, but she lacks a desire for knowledge:

I know there must be more than they're telling us, an actual account of what happened during the rebellion. But I don't spend much time thinking about it. Whatever the truth is, I don't see how it will help me get food on the table. (Collins 2010a, pp. 501)

Katniss' pragmatism is arguably an asset in the arena, but her apathy towards the history of Panem may also provide a point of entry for reader identification. The urgency and immediacy of everyday concerns makes fields such as history and politics-over which she has no control—distant and uninspiring.

Katniss does not grasp her fellow tributes' insight into the Capitol's game-making agenda until late in the trilogy. In The Hunger Games, a dialogue between Katniss and Peeta reveals their differing levels of political engagement:

'I keep wishing I could think of a way to...to show the Capitol they don't own me. That I'm more than just a piece in their Games,' says Peeta.

'But you're not,' I say. 'None of us are. That's how the Games work.'

'OK, but within that framework, there’s still you, there’s still me,' he insists. 'Don’t you see?'

‘A little. Only...no offence, but who cares, Peeta?' I say.

'I do. I mean, what else am I allowed to care about at this point?' (p. 172) 
The divergent trajectories of Peeta’s, Katniss' and, later, Gale’s political engagement allow multiple possibilities for reader identification. Initially, Katniss’ movements from inertia to action are repeatedly apolitical in nature. As she reflects: ‘As usual, it's the thought of Prim's anxious face as she watches me on the screens back home that breaks me from my lethargy' (p. 290). In Mockingjay she reiterates, 'I swear, now that my family and Gale's are out of harm's way, I could run away. Except for one unfinished piece of business. Peeta. If I knew for sure that he was dead, I could just disappear into the woods and never look back' (Collins 2010b, p. 15). Broad (2013) implicitly disapproves of Katniss' motivations on the grounds that she (re)acts out of duty, obedience and guilt rather than acting decisively out of her own sense of agency (pp. 126-7), but Katniss increasingly demonstrates political intuition and agency:

Was it like this then? Seventy-five years or so ago? Did a group of people sit around and cast their votes on initiating the Hunger Games? Was there dissent? Did someone make a case for mercy that was beaten down by the calls for the deaths of the districts' children? ... I weigh my options carefully, think everything through. Keeping my eyes on the rose, I say, 'I vote yes...for Prim’. (Collins 2010b, p. 165)

Although she still lacks historical knowledge, in voting to continue the Hunger Games in Mockingjay, Katniss demonstrates political engagement that is proactive rather than reactive, and strategic rather than retributive.

Katniss' subsequent and final power play-shooting President Coin-demonstrates a political perceptiveness she has struggled to attain throughout the trilogy. Coin's desire for one last Hunger Games would seem a powerful revenge, yet Katniss understands that it is just another way in which youth would be used as disposable weapons. Although the act of assassination is a problematic example of political activism for readers, Katniss' action shows insight born of experience, understanding, and strategy, which takes her beyond selfpreservation to political action.

If the link between history, knowledge, and political agency is implicit in The Hunger Games, it is arguably explicit in Mockingjay. While Katniss' and Peeta's children are to be 
brought up in a society that is literally built on the past-they 'don't know they play on a graveyard'-the epilogue highlights the role of memorials, education, and storytelling to 'make them understand in a way that will make them braver' (2010b, p. 173). It highlights the importance of knowledge of the past as a catalyst to bring about political and ideological renewal. This is a central theme in each of the trilogies, and one that is a key to the discussion of political agency: reactionary responses to threatened personal comfort and safety are far less sustainable than revolutionary action based on historical and political knowledge of oppression. Katniss' lack of political will may not recommend her as the best role model for the movement from inertia to action, but her journey towards engagement with the past to act in the present maps out significant markers for readers to identify and emulate.

Veronica Roth's female protagonist, Beatrice ‘Tris’ Prior, begins from a very different place in Divergent. Roth explains:

I did set myself a rule that was hard to follow [...]: Beatrice is always the agent. That is, she’s always choosing, always acting, always moving the plot by her behavior. I don't know that I succeeded in keeping that rule, but it was helpful for me when trying to create an active, rather than a passive or reactive, character. (Allan 2014)

Tris' 'innate' urge to act is consequently evident in the opening chapters of Divergent. The day before the Choosing Ceremony, in which she has the power to determine her future peers, instructors, and actions, she is threatened by a factionless man, who grabs her wrist. In spite of being a member of the self-effacing Abnegation faction, Tris is prepared: 'I am ready. I know what to do. I picture myself bringing my elbow back and hitting him. I see the bag of apples flying away from me. I hear my running footsteps. I am prepared to act' (Roth 2011, p. 26). Tris' articulation of her preparedness to act becomes a motif throughout the trilogy. In Insurgent she reflects: 'By now I know how terror works: I let it for a few seconds, and then force myself to act' (2012, p. 184). Although repeatedly finding herself immobilised by fear or depression, Tris develops the self-knowledge needed to override these affective responses and engage her will to act. 
The will to act subsequently becomes a touchstone of courage or cowardice in the Divergent trilogy. Those who do not act autonomously are despised and ostracised for weakness. In the following passage, this message is reinforced through a sequence that mirrors Tris and Tobias' exchange — cited in the epigraph—on the Ferris wheel:

'But what...' Peter yawns through his words. 'What does firing a gun have to do with...bravery?'

Four flips the gun in his hand, presses the barrel to Peter's forehead, and clicks a bullet into place. Peter freezes with his lips parted, the yawn dead in his mouth.

'Wake. Up,' Four snaps. 'You are holding a loaded gun, you idiot. Act like it.' (2011, p. 77)

Unlike Collins, who positions the reader to journey from inertia to action with Katniss, Roth's youth are inherently powerful with revolutionary potential-the proverbial loaded gun-and those who are apathetic to its power are, or should be, outsiders. As Tris reflects about Dauntless recruit Al: 'If he is a coward, it isn't because he doesn't enjoy pain. It is because he refuses to act' (2011, p. 116). Later, Peter's shame over his cowardice leads him to request a type of mental suicide through voluntary memory loss. Such passages indicate a didactic agenda on Roth's part, but the implied criticism of contemporary (inert) adolescents here may, as Ostry (2013) suggests, lead the reader to react negatively and disengage from an empathic response to the protagonists (p. 110). Thus, Roth's positioning of readers for narrative empathy may be problematic.

It initially appears that the young people in Divergent are in the same 'waiting place' that teenagers encounter in real life-students at school, they are awaiting aptitude tests that will help them to determine their post-school future. Once Tris makes the choice to join the Dauntless Faction, Roth provides her heroine and the other initiates of her age group with situations that allow them far more power than would be available to the typical reader. They are taught to fight and use weapons; they face psychological torture and are expected to take part in extremely dangerous activities; their youth is celebrated for its physical power. The Dauntless youth are allowed to access the part of themselves that is often repressed in the real world, and the questionable morality of Tris' and Tobias' violent actions is overridden by the states of emergency in which they find themselves. At first, the narrative-like the first round of challenges in each book-may appear to promote revolution through violent action. 
However, successive readings or a mature reader response, suggests that the text calls upon readers to recognise that the real power on offer is knowledge-ways of discovering power structures through memory and history. In repeatedly placing Tris in situations that require her to engage the 'planning processor' (Mar et al. 2011, p. 824)— the 'cognitive mechanism' by which goals are set and actions accomplished-the text invites readers to consider the complexity of, and appropriate ways to negotiate, power.

Tris' attitude to political and historical knowledge is therefore quite different to Katniss'. The showdown between Tris and Jeanine in Insurgent, which results in the release of suppressed historical documents, highlights Tris' need to know about the past. The revelations about her ancestor Edith 'Prior' underscore the importance of the past as a key to understanding the present and to determining the future. Accurate historical knowledge is Tris' catalyst for effective action. She is also more self-aware than Katniss, repeatedly analysing the reasons behind her own actions. Her self-sacrifice when delivering herself to the Erudite compound in many ways mirrors Katniss' choice to volunteer as Tribute to save her sister, but Tris is aware of her own need to escape self-flagellation after making reactive choices that left two of her friends dead. Later, Tris is unapologetic about an intervention strategy informed by political history. To Tobias' question about the ethics of turning the Bureau's 'resetting' agenda back on itself, for example, Tris responds: “"The difference is what's right," [she says] firmly. "The people in the city, as a whole, are innocent. The people in the Bureau...are not innocent”' (Roth 2013, p. 388). As Seymour (2015) notes, Tris' choices are finally 'more active', representing 'deliberate expressions of agency' as her knowledge of the political situation increases (p. 5).

Like the teenagers in The Hunger Games and Divergent trilogies, the protagonist of The Maze Runner begins his story in a waiting space. Thomas wakes up to find himself in the Glade, a simulated world where adolescents are tested and approved or rejected for further levels of mental and physical trauma. The ultimate aim of such testing is to identify individuals who have the power to save mankind from The Flare, a disease developed for biological warfare and released in an attempt at population control. At the beginning of the narrative, readers are as ill-informed as Thomas. He has no memory of the past, so must wait, learning the ropes in an uncannily familiar place until Teresa-the catalyst for action and Thomas' initial love interest-arrives. Thomas is driven by a desire for knowledge, and is 
disturbed by his fellow Gladers’ lack of curiosity and apparent apathy about their situation. Chuck, Thomas' surrogate brother, explains:

'That's just the way it is. Things are really weird around here, and most of us don't know everything. Half of everything.' It bothered Thomas that Chuck didn't seem to care about what he'd just said. That he seemed indifferent to having his life taken away from him. What was wrong with these people? Thomas got to his feet and started walking.... He needed to learn something or he was going to lose his mind. (Dashner 2010, p. 24)

Here, Thomas is the model of physical and psychological agency; just as it is for Roth's protagonists in dystopian Chicago, knowing the past is the key to understanding the present. The Gladers are fixated on survival when Thomas arrives, but it soon becomes apparent to him that settling for simple survival leads to defeat. His decision to take action produces much tension between Thomas and the Gladers. Alby, the group's influential leader, becomes frustrated with Thomas:

'Boy, you ain’t learned nothin’ since showing up in that Box. This ain’t got nothin’ to do with no hate or like or love or friends or anything. All we care about is surviving. Drop your sissy side and start using that shuck brain if you got one.' (2010, p. 84)

The irony of Alby's directive to 'start using that shuck brain' is that Thomas is repeatedly 'accused of knowing things' the other Gladers do not know, and this drives more of a wedge between them (2010 p. 84). In a deeper irony, it is Thomas' lack of memory that drives him to discover the truth of the Gladers' situation, which again signals the connection between agency, power, and knowledge. Thomas' desire to 'know' spurs him into action, demonstrating true agency in the face of an oppressive, unknown enemy.

Throughout the trilogy, Thomas experiences periods of despondency and depression as information is repeatedly withheld from him. However, after such periods, Thomas realises the need to act: 'it was as if his body craved the action' (2011, p. 78). On multiple occasions, action is enough to renew his hope: 'Thomas knew they couldn't waste any more time. No questions, no fear, no bickering. Only action' (2011, p. 341). When, in the final chapters of The Death Cure, he finally understands that the enigmatic government agency, WICKED, 
has used unethical means for an ostensibly moral cause, Thomas questions his complicity with its agenda. However, despite his ethical struggles with his role in supporting WICKED, the morality of Thomas' will to act is never questionable. While the 'far-fetched' nature of the trilogy's premise may cause the books 'to be read ultimately as flights of fancy rather than projections of a possible future' (Hintz et al. 2013, p. 4), Miall and Kuiken (2002) might argue that the trilogy's power is in its potential to 'produce metaphors of personal identification that modify self-understanding' (p. 229). That is, the Maze Runner series models the desire for knowledge triggering action and ethical thinking in the face of severe cultural, social, historical and physical dislocation.

In all of these series, a possible impediment to reader identification and empathy is the exceptional nature of the protagonists. Despite the invitation to identify with the characters' self-deprecation, self-doubt and-at times—self-loathing, Tris, Tobias, Thomas, and Katniss are not average teenagers. All are physically and mentally exceptional. As scholars have noted, 'denied legal and social power, teenagers in [YA dystopian fiction] often wield awesome mind control' (Hintz et al. 2013, pp. 9-10). All four protagonists resist technological forms of mind control, and Katniss has the strength of mind to outplay the Gamemakers. Roth's heroine Tris is exceptional among her Dauntless peers because of her Divergent status. While most of the Dauntless are left powerless by the Erudite mind control serum, Tris is not. She and her partner, Tobias, are the sole purveyors of physical justice: they are not even held in check by Dauntless norms. Tris is almost untouchable, immune not only to fear simulations and truth serum, and later, the seemingly inescapable death serum. Her ability to survive danger borders on supernatural. Like the divergent Tris, and also through a quirky twist of genetic fate, Thomas is unaffected by the Flare. Meanwhile, Katniss' exceptional abilities are recognised by everyone but herself until Mockingjay, where she starts to understand how others see her. After she lulls the mockingjays to join her in the melody of 'The Hanging Tree', leader of the rebellion Plutarch Heavensbee throws his arm around her, kisses her on the top of her head and exclaims: 'You're golden!' and 'Where do you come up with this stuff? No one would believe it if we made it up!' (Collins 2010b, pp. 126-7). Understood from a non-empathic reading position, this line may be read ironically, reinforcing the gulf between Katniss' seemingly endless ability to effect change and the reader's real-world experience. 
In each series, the protagonists embody the traits of youth most suppressed in contemporary society: they have the power to take action. The fictional nature of the dystopian form delivers the author from any obligation to verisimilitude. Power and success is limited to 'unique' individuals. Might these exceptional protagonists, then, produce a feeling of powerlessness in their readers? Do these texts issue calls to action that one can never take? The remarkable success of each of these trilogies suggests the opposite is true-that readers can arguably enjoy the protagonists' success without feeling disempowered, in spite of realworld roadblocks to the kind of autonomy played out in the narratives. Paradoxically, however, by experiencing power vicariously through their identification with YA protagonists, adolescents may also sate their desire for action, and return to everyday life with less of a desire for political action. This is an important point in the evaluation of YA dystopian fiction as calls to action: the act of consuming YA fiction's power may in fact erase the readers' need to exercise it. Consumption in this context becomes a form of repressionthe thematic irony of The Hunger Games enacted upon the intended readership.

Furthermore, the protagonists in all three trilogies are forced to take action through the machinations of the game makers. Whether they represent the Capitol, WICKED, Erudite, or the Bureau of Genetic Welfare, the game makers-much like the authors of the texts in which they appear-make the rules, withhold knowledge, and represent the adult world. Trites, again, notes that authors themselves become authority figures in adolescent literature. She writes that 'the mechanisms by which [authors] manipulate the reader to assume subject positions that are carefully constructed to perpetuate the status quo bear investigation' (1998, p. xii). Strong focalisation and limited point of view in each text ensures that historical and political knowledge is withheld from the reader as well as the protagonist. This positions the reader to share the affective experience of revelation with the protagonist. The key difference is that the reader receives information fed by the author, while the protagonist fights for it. Hence, might not the genre of YA dystopian fiction undermine its own instructive potential? The mind control of Tris, Tobias, and Thomas is a metaphor for out-thinking the game makers in our society, but an immersive experience eliciting narrative empathy may produce very different affective responses to those modeled by these young adults. This is not to deny that reading is an active process, but it is important to note that the ideological and affective domains are to some extent in opposition here. 
It is difficult to chart the impact of series as new as the Maze Runner and Divergent trilogies. In fact, Divergent creator Veronica Roth claims that she has 'never felt wise or old enough to point the finger at society' and is 'more interested in the personal', a position perhaps belied by the social and political criticism inherent in her choice of genre (Kidd 2014). The Divergent trilogy has certainly developed a passionate fandom, with over two hundred thousand results arising from a brief internet search for Divergent fan sites. These include interviews with the author, plot summaries, reviews, and 'The Theo James Appreciation Day' (the actor who plays Four) event (Hashtag Avenue 2014), but the activity of the readers appears to be more about engagement with the fan community than the themes of the novel. A 'Camp Divergent' is run by a bookstore in Naperville and makes vague promises about 'literary opportunities', but appears to be more costume play than politically or socially avant garde ('Camp Divergent' 2014). The Maze Runner creator James Dashner is even less willing to commit to an engagement with politics than Roth, claiming that he believes the popularity of his book, and the dystopian genre in general, has 'less to do with readers' views on the current political climate' than it does on the fact that his readership likes a 'cool, compelling story'. He is non-committal about its potential to ignite action, suggesting that it instead 'could serve as a warning' about 'how bad a society could get' (Ellsworth 2011).

Nevertheless, a Hunger Games-inspired student movement supports the contention that YA dystopian fiction can inspire and energise those who are already politically active. Despite bans in the nation's capital, the Thai League of Liberal Thammasat for Democracy (LLTD) appropriated the three-finger salute of the rebellious districts and used it at a silent protest against their own totalitarian regime, claiming the gestures stands for 'liberty, equality, fraternity' (Tharoor 2014). Activist Manik Sethisuwan tweeted of the move: 'Dear \#HungerGames. We've taken your sign as our own. Our struggle is non-fiction. Thanks. \#ThaiCoup \#Thailand' (Leins 2014). This is not the first time the salute has been appropriated. The Harry Potter Alliance has used the salute in its 'Odds in Our Favour' campaign against economic inequality with the tag line: 'When we shift the narrative, we can shift the culture’ (Harry Potter Alliance 2014).

Such appropriation has elicited a range of responses. Social commentators and scholars such as Ashley Hinck (2012b) emphasise the difference between media and civic engagementthe latter being 'large-scale mobilizations of fans that also affect political institutions' )—but suggest it is legitimate to use popular culture as a resource, appropriating power already 
imbued through performance and an extensive audience (2012a). Conversely, Jonathan Jones (2014) of The Guardian has condemned appropriation of the salute, believing it to reveal 'something about the bankruptcy of political beliefs in the $21^{\text {st }}$ century', and claiming that the Hunger Games' dystopian setting 'has nothing to do with reality'. In fact, the parallels are strong. In both worlds, the salute is recognisable for its protest against rights violations, control over knowledge production and dictatorship (Haberkorn 2014), as it promotes the basic principles of liberal democracy against political and social injustice ('LLTD' 2015). It may, therefore, be contended that the empathic engagement with YA dystopian fiction has produced 'metaphors of personal identification' (Miall and Kuiken 2002, p. 229), and that students have effectively appropriated symbols that represent parallels between theirs and Katniss’ experience of oppression.

It often takes a catalyst to trigger a movement from inertia to action in a generation of young adults. However, as Thai activist Sethisuwan indicates, if political movements are not necessarily triggered by texts such as those under consideration in this paper, they can be inspired and energised by the political agency and action exemplified by YA protagonists. In a society that has constructed, labeled, and limited adolescence, YA dystopian fiction is demonstrably a cognitive and affective space where young adults learn patterns of thinking and action to help them actively negotiate the political world. However, if YA dystopian literature aims to provide its readers with keys to action, it is important to recognise that these keys can both open and lock the gates to political agency.

\section{References}

Allan, Joe (2014). Becoming Divergent: An Unofficial Biography of Shailene Woodley and Theo James. London: Michael O’Mara.

Basu, Balaka, Katherine R. Broad and Carrie Hintz (eds) (2013). Contemporary Dystopian Fiction for Young Adults: Brave New Teenagers. New York: Routledge.

Broad, Katherine R. (2013). ‘The Dandelion in the Spring’. In Basu et al. (eds). Contemporary Dystopian Fiction for Young Adults: Brave New Teenagers. New York: Routledge, pp. 69-84.

Butler, Judith (1990). Gender Trouble: Feminism and the Subversion of Identity. London: Routledge. 
'Camp Divergent'. (2014). [Bookstore]. Retrieved 7 July 2014, from http://www.andersonsbookshop.com/camp-divergent

Collins, Suzanne. (2010a). The Hunger Games. New York: Scholastic.

---. (2010b). Mockingjay. New York: Scholastic.

---.. (2013). Catching Fire. New York: Scholastic.

Couzelis, Mary J. (2013). 'The Future Is Pale: Race in Contemporary Young Adult Dystopian Novels'. In Balaka Basu, Katherine R. Broad and Carrie Hintz (eds). Contemporary Dystopian Fiction for Young Adults: Brave New Teenagers. New York: Routledge. pp. 131-144.

Dashner, James (2010). The Maze Runner. Somerset: The Chicken House.

---. (2011). The Scorch Trials. New York: Delacorte Press.

---. (2013). The Death Cure. New York: Delacorte Press.

Ellsworth, Emily (2011, October 8). 'James Dashner reflects on the end of "The Maze Runner” series’. Deseret News. Retrieved from http://www.deseretnews.com/

Epstein, Robert (2007). 'The Myth of the Teen Brain’. Scientific American 17 (2): 68-75.

Foucault, Michel (1980). Power/Knowledge: Selected Interviews and Other Writings 1972-1977, ed. Colin Gordon. New York: Pantheon.

Haberkorn, Tyrell (2014, October 6). 'Martial Law and the Criminalization of Thought in Thailand'. The Asia-Pacific Journal 12 (40). Retrieved from http://www.japanfocus.org

Harry Potter Alliance (2014). Odds In Our Favor. Retrieved from http://oddsinourfavor.org Hashtag Avenue (2014). Retrieved from http://trisandfour.com/

Hinck, Ashley (2012a). 'Popular Culture and Politics: The Hunger Games 3-Finger Salute in Thai Protests'. Antenna. Retrieved from http://blog.commarts.wisc.edu

Hinck, Ashley (2012b). ‘Theorizing a Public Engagement Keystone: Seeing Fandom’s Integral Connection to Civic Engagement through the Case of the Harry Potter Alliance'. Transformative Works and Cultures 10. Retrieved from http://journal.transformativeworks.org

Hintz, Carrie and Elaine Ostry (eds) (2003). Utopian and Dystopian Writing for Children and Adults. New York: Routledge. 
Jones, Jonathan (2014, June 3). ‘The Thai protesters’ Hunger Games Salute Shows a Lack of Political Thought'. The Guardian. Retrieved from http://www.theguardian.com

Keen, Suzanne (2006). ‘A Theory of Narrative Empathy’. Narrative 14 (3): 207-236.

---. (2007). Empathy and the Novel. Oxford: Oxford University Press.

---. (2008). 'Strategic Empathizing: Techniques of Bounded, Ambassadorial, and Broadcast Strategic Empathy’. Deutsche Vierteljahrsschrift für Literaturwissenschaft und Geistesgeschichte. Stuttgart: Verlag J. B. Metzler, pp. 477-93.

Kidd, James (2014, January 5). “"I Don’t Want Smut on the Page”: Divergent Author Veronica Roth on Sex and Teen Fiction'. Independent. Retrieved from http://www.independent.co.uk

League of Liberal Thammasat for Democracy (LLTD) (2015, June 1). Retrieved from https://www.facebook.com/lltd.tu

Leins, Casey (2014, June 3). 'Thailand Military to Take Action Against "Hunger Games”'. Saluters. Retrieved from www.usnews.com

Mar, R. A., K. Oatley, M. Djikic and J. Mullin (2011). 'Emotion and Narrative Fiction: Interactive Influences Before, During, and After Reading'. Cognition \& Emotion 25 (5): 818-833.

Miall, David S. and Don Kuiken (2002). 'A Feeling for Fiction: Becoming What We Behold’. Poetics 30 (4): 221-241.

Morrissey, Thomas J. (2013). 'Parables for the Postmodern, Post-9/11, and Posthuman World: Carrie Ryan’s Forest of Hands and Teeth Books, M. T. Anderson's Feed, and Mary E. Pearson's The Adoration of Jenna Fox'. In Basu et al. New York: Routledge, pp. 189-202.

Oatley, Keith (2009). 'Communications to Self and Others: Emotional Experience and its Skills’. Emotion Review 1 (3): 206-213.

Ostry, Elaine (2013). 'On the Brink: The Role of Young Adult Culture in Environmental Degradation’. In Contemporary Dystopian Fiction for Young Adults: Brave New Teenagers. New York: Routledge, pp. 101-116.

Roth, Veronica (2011). Divergent. London: HarperCollins.

---. (2012). Insurgent. London: HarperCollins.

---. (2013). Allegiant. New York: Katherine Tegen.

Seymour, Jessica (2015). 'Re-claiming Adolescent Power in YA Dystopia’. Paper presented at the MLA Annual Convention, Vancouver. 
Sibley, David (1995). Geographies of Exclusion: Society and Difference in the West. London: Routledge.

Simmons, Amber M. (2012). 'Class on Fire: Using the Hunger Games Trilogy to Encourage Social Action’. Journal of Adolescent \& Adult Literacy 56 (1): 22- 34.

Skelton, Tracey and Gill Valentine (eds) (1998). Cool Places: Geographies of Youth Cultures. London: Routledge.

Tharoor, Ishaan (2014, 20 November). 'Why are China and Thailand scared of the “Hunger Games”?’ The Washington Post. Retrieved from http://www.washingtonpost.com

Trites, Roberta Seelinger (1998). Disturbing the Universe: Power and Repression in Adolescent Literature. Iowa City: University of Iowa Press.

\section{Biographical Notes}

Lindsay Morton lectures in English literature and Communication at Avondale College of Higher Education. Her research interests include narrative literary journalism, contemporary young adult and Australian literature, and the power of both fiction and narrative non-fiction to affect political change.

Lynnette Lounsbury lectures in Writing and Ancient History at Avondale College of Higher Education in Cooranbong, NSW. She is the author of the YA novel Afterworld (Allen \& Unwin, 2014) and editor of the travel website for young writers - YTraveler.com. 